\title{
The aeration effect in pilot reed bed to phytoremediate water containing Lead $(\mathrm{Pb})$
}

\author{
Bieby Voijant Tangahu ${ }^{1 \otimes}$, Siti Rozaimah Sheikh Abdullah ${ }^{2}$, Hassan Basri $^{3}$, Mushrifah Idris ${ }^{4}$, Nurina \\ Anuar $^{2}$ and Muhammad Mukhlisin ${ }^{3}$
}

\begin{abstract}
A pilot reed bed study was conducted with the aid of aeration to remove lead $(\mathrm{Pb})$ contaminated water using Scirpus grossus $\mathrm{L}$. f. The plants were grown in sand medium in pilot-scale reed beds, and exposed to water containing $P b$ in a various concentration $(10,30$ and 50 $\mathrm{mg} / \mathrm{L}$ ) with aeration rate of $2 \mathrm{~L} / \mathrm{min}$. The samples were taken on day-1, day-14, day-28, day-42, day-70 and day-98. The results showed that $\mathrm{Pb}$ concentration in water decreased $74 \%$ on day-7, $80 \%$ on day-14, $99 \%$ on day-28 and reach $100 \%$ on day-48 for treatment $10 \mathrm{mg} / \mathrm{L}$. $\mathrm{Pb}$ concentration decreased $91 \%$ on day- $7,93 \%$ on day-14 and then on the day-28 the reduction reached $\mathbf{9 9 \%}$ for treatment of $30 \mathrm{mg} / \mathrm{L}$. For $\mathrm{Pb}$ treatment of $\mathbf{5 0}$ $\mathrm{mg} / \mathrm{L}$, the reduction reached $92 \%$ on day- $7,96 \%$ on day-14, and $99 \%$ on day-28. The sand adsorbed $\mathrm{Pb}$ up to $7.91 \times 10^{-4} \mathrm{mg} / \mathrm{kg}$ for $10 \mathrm{mg} / \mathrm{L}, 1.07 \times 10^{-3} \mathrm{mg} / \mathrm{kg}$ for 30 $\mathrm{mg} / \mathrm{L}$ and $2.41 \times 10^{-3} \mathrm{mg} / \mathrm{kg}$ for $50 \mathrm{mg} / \mathrm{L}$. Pb uptake by plant was $2286 \mathrm{mg} / \mathrm{kg}$ on day-98, $4174 \mathrm{mg} / \mathrm{L}$ on day-28
\end{abstract}

Received: 20 September 2014

Accepted revised version: 21 February 2015

Published online: 01 April 2015

(C) Tangahu et al., (2015)

Publisher: Horizon e-Publishing Group

\section{CITATION}

Tangahu, B. V., S. R. S. Abdullah, H. Basri, M. Idris, N. Anuar, and M. Mukhlisin. 2015. The aeration effect in pilot reed bed to phytoremediate water containing Lead (Pb). Plant Science Today 2(2): 52-55. doi: 10.14719/pst.2015.2.2.84

\section{AUTHOR'S AFFILIATION}

1 Department of Environmental Engineering, Faculty of Civil Engineering and Planning, Sepuluh Nopember Institute of Technology (ITS), Kampus ITS Sukolilo, Surabaya 60111, Indonesia

2 Department of Chemical and Process Engineering, Faculty of Engineering and Built Environment, Universiti Kebangsaan Malaysia (UKM), 43600 UKM Bangi, Selangor, Malaysia

3 Department of Civil and Structural Engineering, Faculty of Engineering and Built Environment, Universiti Kebangsaan Malaysia (UKM), 43600 UKM Bangi, Selangor, Malaysia

4 Tasik Chini Reasearch Centre, Faculty of Science and Technology, Universiti Kebangsaan Malaysia (UKM), 43600 UKM Bangi, Selangor, Malaysia

CORRESPONDENCE

凶Bieby Voijant Tangahu - Email: voijant@its.ac.id and $8297 \mathrm{mg} / \mathrm{kg}$ on day-14 for 10,30 and $50 \mathrm{mg} / \mathrm{L}$, respectively. The highest Bioaccumulation Concentration (BC) was 10618 for $10 \mathrm{mg} / \mathrm{L}$ on day-28, 81311 for 30 $\mathrm{mg} / \mathrm{L}$ and 81467 for $50 \mathrm{mg} / \mathrm{L}$ both on day-42, with the Translocation Factor (TF) related to the same day of these $\mathrm{BC}$ were $0.13,0.24$, and 0.35 respectively. The highest TF value for $10 \mathrm{mg} / \mathrm{L}$ were 0.7 on day-98, 0.38 for $30 \mathrm{mg} / \mathrm{L}$ on day-70 and 0.59 for $50 \mathrm{mg} / \mathrm{L}$ on day-14.

Keywords: aeration; bioaccumulation; lead; phytoremediation; Scirpus grossus reed bed

\section{Introduction}

Phytoremediation becomes a popular method and has been identified as an effective and affordable technological solution for extraction or removal of inactive metals and metal pollutants from contaminated soil and water (Cho-Ruk et al., 2006). Compared to other conventional methods, phytoremediation technology is environmental friendly, low-cost, aesthetically pleasing and less disrupting, effective in reducing contaminant and applicable for wide range of contaminant (Salido, et al., 2003). In this method, plants, particularly those with exceptional metal-accumulating capacity have been known as hyperaccumulator plants (Cho-Ruk et al., 2006).

According to the list of the top ten priority hazardous substances (ATSDR, 2011), lead (Pb), a heavy metal, is on the second place. Due to the widest range of Lead $(\mathrm{Pb})$ sources, this metal also becomes one of the most toxic metals that can be biologically accumulated and concentrated (Sharma and Dubey, 2005). Inorganic $\mathrm{Pb}$ is harmful to the nervous system because it can act as an inhibitor enzyme. $\mathrm{Pb}$ can enter the human body through drinking water, food or air (Sharma and Dubey, 2005) through its ionic form which is the most toxic.

Reed bed system is a technology to treat wastewater, which is used to activate microbial processes that will stimulate the natural breakdown of polluting compounds in a specific waste water situation. This kind of treatment is possible due to the special characteristics of wetland 
plants, such as reeds, which can transfer substantial amounts of atmospheric oxygen through their root systems encouraging an extraordinary quantity and
Jinadasa, et al., 2006b; Jinadasa, et al., 2008). In our previous study showed that $S$. grossus can phytoremediate $\mathrm{Pb}$-contained water without aeration (Tangahu et al.,

Table 1. Bioaccumulation Coefficient (BC) and Translocation Factor (TF)

\begin{tabular}{|c|c|c|c|c|c|c|}
\hline \multirow{3}{*}{ Observation } & \multicolumn{6}{|c|}{ Treatment } \\
\hline & \multicolumn{2}{|c|}{$10 \mathrm{mg} / \mathrm{L} \mathrm{Pb}$} & \multicolumn{2}{|c|}{$30 \mathrm{mg} / \mathrm{L} \mathrm{Pb}$} & \multicolumn{2}{|c|}{$50 \mathrm{mg} / \mathrm{L} \mathrm{Pb}$} \\
\hline & BC & TF & BC & TF & BC & TF \\
\hline Day-1 & 125.31 & 0.30 & 49.13 & 0.25 & 28.18 & 0.25 \\
\hline Day-7 & 555.39 & 0.31 & 712.00 & 0.26 & 1237.42 & 0.53 \\
\hline Day-14 & 809.23 & 0.33 & 1193.50 & 0.27 & 4231.10 & 0.59 \\
\hline Day-28 & 10608.05 & 0.14 & 14513.82 & 0.33 & 11455.64 & 0.20 \\
\hline Day-42 & $\mathrm{N} / \mathrm{A}$ & 0.20 & 81311.38 & 0.24 & 81467.36 & 0.35 \\
\hline Day-70 & $\mathrm{N} / \mathrm{A}$ & 0.13 & $\mathrm{~N} / \mathrm{A}$ & 0.38 & $\mathrm{~N} / \mathrm{A}$ & 0.06 \\
\hline Day-98 & $\mathrm{N} / \mathrm{A}$ & 0.70 & $\mathrm{~N} / \mathrm{A}$ & 0.24 & $\mathrm{~N} / \mathrm{A}$ & 0.21 \\
\hline
\end{tabular}

$\mathrm{N} / \mathrm{A}=$ no $\mathrm{Pb}$ detected in solution medium

species diversity of micro-organisms to flourish around their roots (Ecotechnologies International, 2011). A reed bed is a channel that is filled with gravel and planted with macrophytes i.e. reeds, rushes and used to treat wastewater. Inlet and outlet pipes are positioned below the gravel surface, so that the water always remains below the gravel surface, thus excluding human exposure to the wastewater, mosquito breeding and unpleasant odors (Lismore City Council, 2004).

To evaluate the efficiency of plants used to accumulate heavy metals for phytoremediation, values of bioaccumulation coefficient (BC) and translocation factor (TF) can be calculated. These parameters represent the capability of the plant to absorb, to transport and to store contaminants in the above-ground part of plant (Haque et al., 2008). It is known that hyperaccumulator plants can 10 - 500 times more than non-hyperaccumulator plants (Rotkittikhun et al., 2006). BC is used to evaluate metal accumulation efficiency in the plant, however, TF is related to the translocation ability of the plant and also, it is the ability to transfer heavy metals from root to above-ground parts (Liu, et al., 2009). In different plant, the metal translocation process is an important factor to determine the metal distribution inside the tissues (Singh et al., 2010).

Scirpus grossus L. f. (Cyperaceae) is used in this study due to its potential consideration as a hyperaccumulator plant as shown in our previous study of $\mathrm{Pb}$ phytotoxicity test (Tangahu et al., 2013b). This plant has fibrous roots in white to brown color, triangular and solid stems, more than $2 \mathrm{~m}$ long leaves, with bisexual flowers grouped together (Weed Science Society of America, 2011). It is a perennial tropical aquatic plant, the common names are giant bulrush, greater club-rush and rumput menderong (Malaysia), mensiang, and walingi (Indonesia). This plant is also widely used in phytoremediation or in wetland to treat domestic wastewater (Jinadasa, et al., 2006a; 2013a) by its accumulation inside the plant tissues. However in this study, aeration is showed to enhance the performance of phytoremediation process.

\section{Materials and Methods}

A pilot reed bed in a single exposure system using lead as the contaminant was conducted with aeration supply of 2 $\mathrm{L} / \mathrm{min}$ flow rate using an air compressor pump (Orimas HP2, Malaysia). The contaminant concentrations used were 0 (control), 10,30 , and $50 \mathrm{mg} / \mathrm{L}$ using $\mathrm{Pb}\left(\mathrm{NO}_{3}\right)_{2}(\mathrm{R} \&$ $\mathrm{M}$ chemicals, U.S.) diluted in tap water. The second generation and same age plants with similar height of around $80 \mathrm{~cm}$ were selected to undergo this pilot study. The plants were grown in batch tanks (L180 x W90 x $H 90 \mathrm{~cm}$ ) in a bed of inert granular substrate (coarse gravel, fine gravel and sand). Ratio of plant number and total mass contaminant which was used in this reed bed tank was 0.002 .

The phytoremediation response was observed with the wet and dry weight of plant tissues (root, stem and leaf), $\mathrm{Pb}$ concentration in water, sand and plant tissue. The observation was starting on day- 0 for water and on day- 1 for sand and plant tissue, continuing on day-7, day-14, day-28, day-42, day-70 and day-98.

\section{Results and Discussion}

The plant wet weight increased up to day-14 for treatment 0 and $30 \mathrm{mg} / \mathrm{L}$ and decreased the day after. For treatment 10 and $50 \mathrm{mg} / \mathrm{L}$, wet weight increased up to day-28 and then decreased the day after. The dry weight measurement also showed the same trends between all treatments.

As shown in Fig. 1, Pb concentration in water decreased starting from the day-7 and became $0 \mathrm{mg} / \mathrm{L}$ on day-42 for all treatment. For treatment of $10 \mathrm{mg} / \mathrm{L}, \mathrm{Pb}$ concentration decreased by $74 \%$ on day- 7 , and become $80 \%$ on day- 14 , $99 \%$ on day-28 then reach $100 \%$ on day- 48 . For the treatment of $30 \mathrm{mg} / \mathrm{L}, \mathrm{Pb}$ concentration decreased by $91 \%$ 


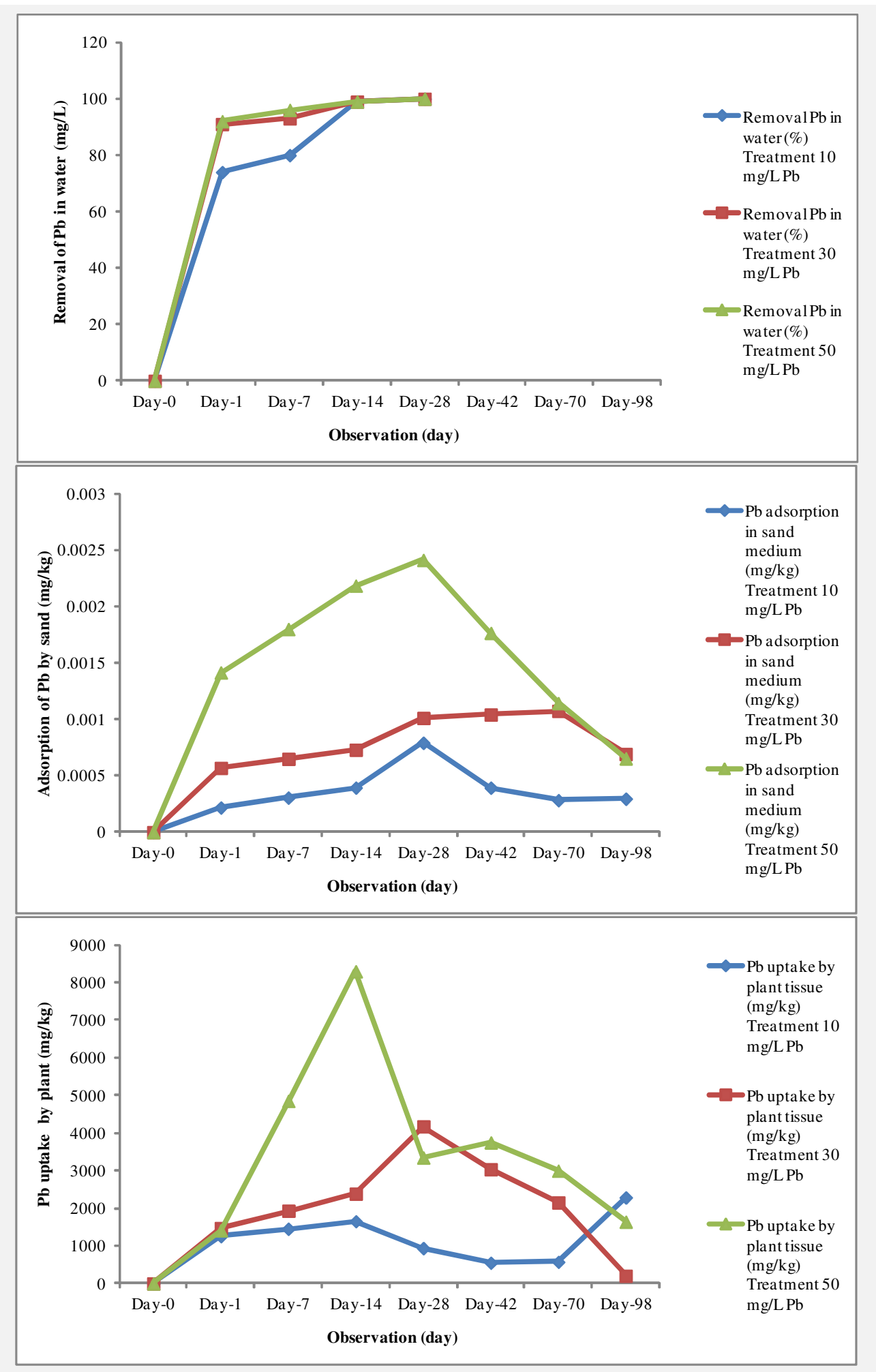

Fig. 1. $\mathrm{Pb}$ removal in water, $\mathrm{Pb}$ adsorption by sand and $\mathrm{Pb}$ uptake by plant

on day-7, the reduction became $93 \%$ on day-14 and then on the day-28, reduction reach $99 \%$. On treatment 50 $\mathrm{mg} / \mathrm{L}$, reduction reach $92 \%$ on day- 7 and become $96 \%$ on day-14, then reach $99 \%$ on day- 28 .
$\mathrm{Pb}$ absorbed in sand medium was starting on the day- 1 and increased on day after. The adsorption was highest on the day-28 for treatment $10 \mathrm{mg} / \mathrm{L}$ and $50 \mathrm{mg} / \mathrm{L}$ and decreased until the end of observation. For treatment 30 
$\mathrm{mg} / \mathrm{L}$, the adsorption was stable from day-14 to day-42 and decreased on day after. The highest $\mathrm{Pb}$ adsorption was $7.91 \times 10^{-4} \mathrm{mg} / \mathrm{kg}$ for treatment $10 \mathrm{mg} / \mathrm{L}$, for treatment 30 $\mathrm{mg} / \mathrm{L}$ was reach $1.07 \times 10^{-3} \mathrm{mg} / \mathrm{kg}$ and $2.41 \times 10^{-3} \mathrm{mg} / \mathrm{kg}$ for treatment $50 \mathrm{mg} / \mathrm{L}$ (Fig. 1).

It is also shown on Fig. $1, \mathrm{~Pb}$ concentration in $S$. grossus tissues at treatment $10 \mathrm{mg} / \mathrm{L}$, increased up to day-14 and started to decrease the day after, but became higher at the end of observation on day-98. For treatment 30 and 50 $\mathrm{mg} / \mathrm{L}, \mathrm{Pb}$ concentration increased up to the highest on day-28 and day-14, respectively, and then decreased the day after. The highest $\mathrm{Pb}$ uptakes were $2286 \mathrm{mg} / \mathrm{kg}, 4174$ $\mathrm{mg} / \mathrm{L}$ and $8297 \mathrm{mg} / \mathrm{kg}$ for treatment 10, 30 and $50 \mathrm{mg} / \mathrm{L}$, respectively. $\mathrm{Pb}$ concentration in root was higher than upper side of the plant tissue (shoot and leaf) for all treatments. This trend was also found on the several studies of $\mathrm{Pb}$ phytoremediation by Potamogeton natans (Fritioff and Greger, 2006), Siam weed Chromolaena odorata (L.) King \& Robinson (Tanhan et al., 2007), Phragmites australis (Baldantoni et al., 2009), Brassica juncea (Liu et al., 2000; Meyers et al., 2008). For treatment 30 and $50 \mathrm{mg} / \mathrm{L}, \mathrm{Pb}$ concentrations in roots were found to reach level indicative hyperaccumulation, which the concentration are $>1000 \mathrm{mg} / \mathrm{kg}$ for $\mathrm{Pb}$, compared to a study done by Haque, et al., (2008). On treatment $10 \mathrm{mg} / \mathrm{L}$, $\mathrm{Pb}$ concentration $>1000 \mathrm{mg} / \mathrm{kg}$ reached on day-7 and day-98.

Table 1 shows the Bioaccumulation Coefficient (BC) and Translocation Factor (TF). The BC value for all treatment were $>1$ that was properties of hyperaccumulator plant. The $\mathrm{TF}$ values in all treatment were fluctuated; it was caused by the difference of $\mathrm{Pb}$ concentration in root and shoot depending on the biochemical and physiological factors contributing to heavy metal accumulation and distribution in the upper vegetative parts (Singh et al., 2010).

\section{Conclusions}

The study of aeration effect on phytoremediation of $\mathrm{Pb}$ showed that for treatment $10 \mathrm{mg} / \mathrm{L}$, the concentration of $\mathrm{Pb}$ in water decreased $100 \%$ on day-48. On treatment of 30 $\mathrm{mg} / \mathrm{L}$, the $\mathrm{Pb}$ concentration decreased $99 \%$ on day- 28 and the reduction on treatment $50 \mathrm{mg} / \mathrm{L}$ reached $99 \%$ on day-28. The highest concentration of $\mathrm{Pb}$ adsorption by sand was $7.91 \times 10^{-4} \mathrm{mg} / \mathrm{kg}$ for treatment $10 \mathrm{mg} / \mathrm{L}$, for treatment $30 \mathrm{mg} / \mathrm{L}$ the highest $\mathrm{Pb}$ adsorption was reach $1.07 \times 10^{-3}$ $\mathrm{mg} / \mathrm{kg}$ and $2.41 \times 10^{-3} \mathrm{mg} / \mathrm{kg}$ for treatment $50 \mathrm{mg} / \mathrm{L}$. The highest $\mathrm{Pb}$ uptake by plant reach $2286 \mathrm{mg} / \mathrm{kg}$ on day-98, $4174 \mathrm{mg} / \mathrm{L} 90$ day-28 and $8297 \mathrm{mg} / \mathrm{kg}$ on day-14 for treatment 10,30 and $50 \mathrm{mg} / \mathrm{L}$ respectively. $\mathrm{BC}$ values for all treatment are $>1$, the highest $\mathrm{BC}$ were 10618 for treatment $10 \mathrm{mg} / \mathrm{L}, 81311$ for treatment $30 \mathrm{mg} / \mathrm{L}$ and 27647 for treatment $50 \mathrm{mg} / \mathrm{L}$. TF value for all treatment were $<1$, it shows that the transport of $\mathrm{Pb}$ from lower part to upper part were low because of the low concentration were exposed. The highest TF value for $10 \mathrm{mg} / \mathrm{L}$ were 0.7 on the day-98, 0.38 for $30 \mathrm{mg} / \mathrm{L}$ on day-70 and 0.59 for $50 \mathrm{mg} / \mathrm{L}$ on day-14.

\section{Competing interests}

The authors declare that they have no competing interests.

\section{Acknowledgments}

The authors gratefully acknowledge Indonesian Directorate General of Higher Education for providing a doctoral scholarship for the first author, also acknowledge with thanks the Universiti Kebangsaan Malaysia (FRGS-CC-03-FRGS0119-2010) and Tasik Chini Research Centre for supporting this research project.

\section{References}

ATSDR (Agency for Toxic Substances and Disease Registry). 2011. Detailed Data Table for The 2011 Priority List of Hazardous Substances that will be The Subject of Toxicological Profiles. Retrieved from http://www.atsdr.cdc.gov/spl/resources/ATSDR_2011_SPL_ Detailed_Data_Table.pdf

Baldantoni, D., R. Ligrone, and A. Alfani. 2009. Macro- and trace-element concentrations in leaves and roots of Phragmites australis in a volcanic lake in Southern Italy. Journal of Geochemical Exploration 101: 166-174. doi: 10.1016/j.gexplo.2008.06.007

Cho-Ruk, K., J. Kurukote, P. Supprung, and S. Vetayasuporn. 2006. Perennial plant in the phytoremediation of Lead-contaminated soil. Biotechnology 5(1): 1-4. doi: 10.3923/biotech.2006.1.4

Ecotechnologies International. 2003. Reed Bed Technology. Germany: Ingenieurbüro Blumberg

Fritioff, A., and M. Greger. 2003. Aquatic and terrestrial plant species with potential to remove heavy metals from stormwater. International Journal of Phytoremediation 5 (3): 211-224. doi: 10.1080/713779221 PMid:14750429

Haque, N., J. R. Peralta-Videa, G. L. Jones, T. E. Gill, and L. Jorge Gardea-Torresdey. 2008. Screening the phytoremediation potential of desert broom (Baccharis sarothroides Gray) growing on mine tailings in Arizona, USA. Journal of Environmental Pollution 153(2): 362-368. doi: 10.1016/j.envpol.2007.08.024 PMid:17964035 PMCid:PMC2426961

Jinadasa K. B. S. N., N. Tanaka, M. I. M. Mowjood, D. R. I. and B. Werellagama. 2006b. Free water surface constructed wetlands for domestic wastewater treatment: A tropical case study. Chemistry and Ecology 22(3): 181-191. doi: 10.1080/02757540600658849

Jinadasa, K. B. S. N., N. Tanaka, M. I. M. Mowjood, and D. R. I. B. Werellagama. 2006a. Effectiveness of Scirpus grossus in treatment of domestic wastes in a constructed wetland. Journal of Freshwater Ecology 21(4): 603-612, ISSN 02705060

Jinadasa, K. B., N. Tanaka, S. Sasikala, D. R. Werellagama, M. I. Mowjood, and W. J. Ng. 2008. Impact of harvesting on 
constructed wetlands performance - a comparison between Scirpus grossus and Typha angustifolia. Journal of Environmental Science and Health. Part A Toxic/ Hazardous Substances and Environmental Engineering 43(6): 664-71. doi: 10.1080/10934520801893808 PMid:18393076

Lismore City Council. 2004. The Use of Reed Beds for the Treatment of Sewage \& Wastewater from Domestic Households. Lismore, NSW: Scientific research from Southern Cross University.

Liu, D., W. Jiang, C. Liu, C. Xin, and W. Hou. 2000. Uptake and accumulation of lead by roots, hypocotyls and shoots of Indian mustard [Brassica juncea (L.)]. Bioresource Technology 71: 273-277. doi: 10.1016/S0960-8524(99)00082-6

Liu, Z., X. He, W. Chen, F. Yuan, K. Yan, and D. Tao. 2009. Accumulation and tolerance characteristics of cadmium in a potential hyperaccumulator-Lonicera japonica Thunb. Journal of Hazardous Materials 169: 170-175. doi: 10.1016/j.jhazmat.2009.03.090 PMid:19380199

Meyers, D. E. R., G. J. Auchterlonie, R. I. Webb, and B. Wood. 2008. Uptake and localisation of lead in the root system of Brassica juncea. Environmental Pollution 153: 323-332. doi: 10.1016/j.envpol.2007.08.029 PMid:18191314

Rotkittikhun, P., M. Kruatrachue, R. Chaiyarat, C. Ngernsansaruay, P. Pokethitiyook, A. Paijitprapaporn, and A. J. M. Baker. 2006. Uptake and accumulation of lead by plants from the Bo Ngam lead mine area in Thailand. Environmental Pollution 144: 681-688. doi: 10.1016/j.envpol.2005.12.039 PMid:16533549

Salido, A. L., K. L. Hasty, Jae-Min Lim, and D. J. Butcher. 2003. Phytoremediation of Arsenic and Lead in Contaminated Soil Using Chinese Brake Ferns (Pteris vittata) and Indian Mustard (Brassica juncea). International Journal of Phytoremediation 5(2): 89-103. doi: 10.1080/713610173 PMid:12929493

Sharma, P., and R. S. Dubey. 2005. Lead Toxicity in Plant. Brazilian Journal of Plant Physiology 17(1): 35-52. doi: 10.1590/S1677-04202005000100004

Singh, R., D. P. Singh, N. Kumar, S. K. Bhargava, and S. C. Barman. 2010. Accumulation and translocation of heavy metals in soil and plants from fly ash contaminated area. Journal of Environmental Biology 31: 421-430. Triveni Enterprises, Lucknow (India). PMid:21186714

Tanhan, P., M. Kruatrachue, P. Pokethitiyook, R. Chaiyarat. 2007. Uptake and accumulation of cadmium, lead and zink by Siam weed [Chromolaena odorata (L.) King and Robinson]. Chemosphere 68(2): 323-329.

Tangahu, B. V. , S. R. Sheikh Abdullah, H. Basri, M. Idris, M., N. Anuar, and M. Mukhlisin. 2013a. Phytoremediation of Wastewater Containing Lead (Pb) in Pilot Reed Bed Using Scirpus Grossus. International Journal of Phytoremediation 15(7): 663-676. doi: 10.1080/15226514.2012.723069

Tangahu, B. V. , S. R. Sheikh Abdullah, H. Basri, M. Idris, M., N. Anuar, and M. Mukhlisin. 2013b. Phytotoxicity of wastewater containing lead $(\mathrm{Pb})$ effects Scirpus grossus. International Journal of Phytoremediation 15(8): 814-826. doi: 10.1080/15226514.2012.736437

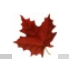

